\title{
Implications of hcv natural genetic diversity on HCV NS5B inhibitor NM283
}

\author{
Victoria L Demetriou*, Leondios G Kostrikis \\ From $16^{\text {th }}$ International Symposium on HIV and Emerging Infectious Diseases \\ Marseille, France. 24-26 March 2010
}

\section{Background}

The HCV NS5B RNA polymerase is a new target for drug development for HCV disease. Valopicitabine (NM283), the prodrug of 2'-C-Methylcytidine (NM107), has been the most clinically advanced NS5B nucleoside inhibitor. Nucleoside inhibitors exhibit similar activity among genotype 1 strains, but their efficacy among other genotypes is largely unknown. In this study NS5B amino acid polymorphisms in positions affecting activity and drug efficacy were investigated in sequences of all $\mathrm{HCV}$ genotypes.

\section{Methods}

NS5B amino acid positions significant for catalytic activity, drug binding and resistance were recovered from bibliography and molecular modelling. NS5B sequences were located and downloaded from the $\mathrm{HCV}$ sequence database, and added to experimentally derived NS5B sequences from drug-naïve patients in order to analyse significant amino acid positions for natural polymorphisms. The most frequent polymorphisms in resistanceconferring position 282 were further investigated by docking analysis.

\section{Results}

The results revealed a highly conserved active site. Natural polymorphisms at position 282 were found at low frequencies, in particular the drug resistant S282T, and S282R, whose effect is unknown. No genotype-specificity of polymorphisms could be confirmed.

\section{Discussion}

The selection of S282T as a drug-resistant variant when S282R also exists naturally at the same frequencies implies that the latter may not confer resistance to

\footnotetext{
* Correspondence: victoria.demetriou@ucy.ac.cy University of Cyprus, Nicosia, Cyprus
}

NM283. Molecular modelling suggests that loss of NM107 activity in the presence of the S282T mutation may be a result from improper alignment of the drug at the active site. Overall, the results imply the need for resistance testing when 2'-C-methyl nucleotide inhibitors are widely available.

Published: 11 May 2010

doi:10.1186/1742-4690-7-S1-P28

Cite this article as: Demetriou and Kostrikis: Implications of hcv natural genetic diversity on HCV NS5B inhibitor NM283. Retrovirology 2010 7(Suppl 1):P28.
Submit your next manuscript to BioMed Central and take full advantage of:

- Convenient online submission

- Thorough peer review

- No space constraints or color figure charges

- Immediate publication on acceptance

- Inclusion in PubMed, CAS, Scopus and Google Scholar

- Research which is freely available for redistribution

Submit your manuscript at www.biomedcentral.com/submit
C Biomed Central 